\title{
Adjuvant Intravesical Chemotherapy in the Management of Superficial Transitional Cell Carcinoma of Urinary Bladder Following Transurethral Resection of Bladder Tumor- Result of Single Dose and Multiple doses of Mitomycin C
}

\author{
Shahriar Md. Kabir Hasan', Kazi Rafiqul Abedin², Md. Shawkat Alam ${ }^{3}$, Anup Roy Chowdhury ${ }^{4}$, Md. \\ Moynul Hoque Chowdhury ${ }^{5}$, A.H.M Mostofa Kamal ${ }^{6}$, Imtiaz Enayetullah ${ }^{7}$, Md. Safiul Alam Babul ${ }^{8}$
}

Received: 19 - 05 - 2020 Accepted: 17 - $07-2020$ Conflicts of interest: None

Keywords: Superficial Transitional Cell Carcinoma of Urinary Bladder, TURBT, Intravesical chemotherapy, Mitomycin C.

\begin{abstract}
Background: Bladder cancer is the second most common cancer of the genitourinary tract. Mitomycin $C$ has been commonly used in a perioperative fashion delivered intravesically immediately after TURBT

Objective: To compare the results of post TURBT immediate single dose and multidose regimen of Mitomycin $C$ therapy in the management of superficial transitional cell carcinoma of the urinary bladder.

Method: The present prospective and comparative interventional study was conducted in the Department of Urology, National Institute of Kidney Diseases and Urology, Sher-E-Bangla Nagar, Dhaka from January 2015 to December 2016. Patients of superficial bladder cancer (tumor size $\leq 3 \mathrm{~cm}$, number $\leq 3$, grade I, II) were randomly included in the 2 groups. The sample size was seventy four (74). Thirty (30) patients were in each group and fourteen (14) were excluded from the study. In MMC single dose group (Group A), single dose of MMC 40mg) $40 \mathrm{ml}$ was started immediately within 24 hours of TURBT. In MMC multi-dose group (Group B) $1^{\text {st }}$ instillation of chemotherapy was started immediately within 24 hours of TURBT and additional instillation (5 instillations) were given as OPD basis and was continued weekly for 5 weeks. Follow-up was done on $3^{\text {rd }}, 6^{\text {th }}, 12^{\text {th }}$ month of initial TURBT.

Results: In this study mean age was $61.8 \pm 13.7$ years in group $A$ and $62.7 \pm 13.6$ years in group B. Male was found 25 (83.3\%) in group A and 26 (86.7\%) in group B. Female was found $5(16.7 \%)$ in group $A$ and $4(13.3 \%)$ in group $B$. Mean size of the tumor was found $2.13 \pm 0.78 \mathrm{~cm}$ in group $A$ and $2.05 \pm 0.84 \mathrm{~cm}$ in group $B$. Mean number of tumor was found $1.8 \pm 0.8$ in group $A$ and $1.9 \pm 0.7$ in group $B$. Tumor grade I was found $23(76.7 \%)$ in group A and $25(83.3 \%)$ in group B. Tumor status Ta of superficial bladder was found $25(83.3 \%)$ in group A and $26(86.7 \%)$ group B. Tumor status T1 of superficial bladder was found $5(16.7 \%)$ in group $A$ and $4(13.3 \%)$ group B. Five $(16.7 \%)$ patients was found recurred in group $A$ and $4(13.3 \%)$ in group $B$ at $6^{\text {th }}$ month follow up. At $12^{\text {th }}$ month follow up, $6(20.0 \%)$ patients was found recurred in group $A$ and $5(16.7 \%)$ in group $B$. Side effect was found in $2(6.7 \%)$ patients in group $B$ and not found in group $A$.

Conclusion: MMC single dose was similar to MMC multi-dose regimen with insignificant difference among the two.
\end{abstract}

1. Assistant Professor, Department of Urology, NIKDU, Dhaka.

2. Professor and Head, Department of Urology, NIKDU, Dhaka.

3. Associate Professor, Department of Urology, NIKDU, Dhaka.

4. Assistant Registrar, Department of Urology, NIKDU, Dhaka.

5. Assistant Professor, Department of Urology,NIKDU, Dhaka.

6. Assistant Registrar, Department of Urology, NIKDU, Dhaka.

7. Assistant Professor, Department of Urology, NIKDU, Dhaka.

8. Assistant Professor, Department of Urology, NIKDU, Dhaka

Correspondence: Dr. Shahriar Md. Kabir Hasan, Assistant Professor Department of Urology, NIKDU, Dhaka, Email: pallab812@gmail.com 


\section{Introduction}

Bladder cancer is the second most common cancer of the genitourinary tract and transitional cell carcinoma (TCC) accounts for more than $90 \%$ of bladder cancers. ${ }^{1}$ When initially diagnosed, about $75 \%$ to $80 \%$ bladder cancers are nonmuscle invasive (NMIBC) (also referred to as "superficial") Among the superficial cancer group, approximately $70 \%$ present as Ta lesions, $20 \%$ as $\mathrm{T} 1$ lesions and $10 \%$ as carcinoma in situ. ${ }^{2}$ The risk of developing bladder cancer at $<75$ years of age is $2 \%$ to $4 \%$ for men and $0.5 \%$ to $1 \%$ for women. ${ }^{3}$ Bladder cancer is the seventh most common malignancy among men in the world. ${ }^{4}$ Bladder cancer is 4 times more common in men than in women. Worldwide, Bladder cancer is the 14 th leading cause of cancer deaths. ${ }^{5}$

The primary goal in managing patients with superficial bladder cancer is to complete removal of the tumor and control the unpredicted risk of recurrence and progression to muscle invasion or distant metastasis.[6]

Transurethral resection of bladder tumor (TURBT) is the first and gold standard treatment option for NMIBC. Complete resection of the tumor should be performed including all areas of suspected CIS and abnormal areas in the prostatic urethra and bladder neck. If extensive CIS is present, mapping biopsies should be obtained and all visible papillary lesions resected. Transurethral resection of bladder tumor should include detrusor muscle (muscularis propria) in the specimen in an attempt to rule out $\mathrm{T} 2$ disease and minimize the risk of under-staging. ${ }^{7}$

Intravesical adjuvant chemotherapy and immunotherapy can be used to prevent recurrence following TURBT. ${ }^{8}$ Intravesical chemotherapeutic agents are Thiotepa, Mitomycin C, Doxorubicin, epirubicin, valrubicin; Gemcitabine and Immunomodulatory agents are Bacillus CalmetteGuerin (BCG), lnterferon's. 9

Recently, Mitomycin C has been commonly used in a perioperative fashion delivered intravesically immediately after TURBT. ${ }^{10}$ Mitomycin C is an antitumor antibiotic that acts by inhibiting DNA synthesis. ${ }^{11}$ Several randomized trials and recent metaanalyses have demonstrated a relative-risk reduction with a single perioperative dose of Mitomycin $C$ in patients with nonmuscle invasive urothelial carcinoma with both low and high-risk features (AUA bladder cancer clinical guideline 2007). The efficacy of MMC is dependent on the concentration at which the drug is administered. The dose commonly used is $40 \mathrm{mg}$ in 40 mL of saline or water. 6
In mild risk non-muscle-invasive tumors, some studies suggest that early intravesical instillation of chemotherapy reduces the risk of recurrence after TURBT. ${ }^{12}$ The EAU guidelines also advocate an immediate single instillation of chemotherapy following TURBT for the treatment of all NMIBC, regardless of level of risk. ${ }^{6}$

The EAU guidelines recommend one immediate single instillation of chemotherapy after TUR, followed by either adjuvant BCG with maintenance ( $\geq 1$ year) or further instillations of chemotherapy (6-12 months) for intermediate-risk NMIBC. ${ }^{6}$

The first year recurrence rate is significantly decreased if MMC is instilled following TUR. MMC is safe and cost effective with minimal and slight local and systemic side effects. Most low grade, low volume tumors would not require any further treatment if MMC is given immediately following TUR. ${ }^{13}$

The present study aims at observing the results of immediate single dose and multi-dose regimen of Intravesical Mitomycin $C$ in the management of superficial bladder cancer after TURBT.

\section{Methods:}

The present prospective and comparative interventional study was conducted in the Department of Urology, National Institute of Kidney Diseases and Urology, Sher-E-Bangla Nagar, Dhaka from January 2015 to December 2016. Total seventy four (74) patients of superficial bladder tumor were included in this study who had undergone transurethral resection followed by immediate single instillation of Mitomycin C. After availability of histopathological examination of resected tumor, those fulfill the selection criteria (TCC of urinary bladder, stage Ta \& T1, grade I \& II, number of tumor $\leq 3$ and size of tumor $\leq 3 \mathrm{~cm}$ ) were randomized into two groups. Group A were provided with immediate single intravesical instillation of Mitomycin C without additional instillations and Group B provided with single dose of intravesical instillation of Mitomycin C immediately with additional 5 instillations (1-week interval for 5 weeks). Both groups were followed-up up to 12 months. Nine patients were excluded due to histopathological report of muscle invasiveness and five patients were excluded due to irregular follow up. Of them two (2) at 6 months follow up, one (1) at 9 months \& another two (2) at 12 months follow up.

After complete TURBT, all the patients received single dose of intravesical Mitomycin C therapy within 24 
hours of TURBT in the postoperative ward after control of macroscopic hematuria.

Patients of both groups were followed up at $3^{\text {rd }}, 6^{\text {th }}$, $9^{\text {th }}, 12^{\text {th }}$ month. During follow-up all patients were evaluated clinically with history and physical examination. Routine blood count, urea, creatinine, urine cytology, ultrasonogram of kidney, ureter, bladder region were carried out. During cystoscopy, primary site of tumor was inspected first, and then general survey of the whole of the interior of bladder was done. TURBT and biopsy of the tumor base was done in those who were found to have recurrences during follow-up. The resected specimen and tissue from the base of the tumor was sent separately for histopathological examination.

\section{Results}

Table-I : Demographic profile of the respondents.

\begin{tabular}{|c|c|c|c|}
\hline & Group A & Group B & Pvalue \\
\hline \multicolumn{4}{|l|}{ Age (years) } \\
\hline Mean $\pm S D$ & $61.8 \pm 13.7$ & $62.7 \pm 13.6$ & $0.799^{\text {ns }}$ \\
\hline Range (min-max) & $36-85$ & $38-84$ & \\
\hline \multicolumn{4}{|l|}{ Sex } \\
\hline Male & $25(83.3)$ & $26(86.7)$ & $0.718^{\text {ns }}$ \\
\hline Female & $5(16.7)$ & $4(13.3)$ & \\
\hline
\end{tabular}

In this study mean age was $61.8 \pm 13.7$ years (range $36-$ 85 years) in group A and $62.7 \pm 13.6$ years (range $38-84$ years) in group B. Age difference was not statically significant between two groups. Male was found 25 $(83.3 \%)$ in group A and $26(86.7 \%)$ in group B. Female was found $5(16.7 \%)$ in group A and $4(13.3 \%)$ in group B. The sex difference was also not statistically significant between two groups.

Table II : Distribution of tumor size in the respondents

\begin{tabular}{lccc}
\hline & Group A & Group B & P value \\
\hline Size of tumor $(\mathrm{cm})$ & $2.13 \pm 0.78$ & $2.05 \pm 0.84$ & $0.704^{\text {ns }}$ \\
Number of tumor & $1.8 \pm 0.8$ & $1.9 \pm 0.7$ & $0.608^{\text {ns }}$ \\
\hline
\end{tabular}

Mean size of the tumor was found $2.13 \pm 0.78 \mathrm{~cm}$ in group A and $2.05 \pm 0.84 \mathrm{~cm}$ in group B. The difference was not statistically significant $(p>0.05)$. Mean number of tumor was found $1.8 \pm 0.8$ in group $A$ and $1.9 \pm 0.7$ in group B. The difference was not statistically significant.
Table III : Distribution of grade of the tumors among the respondents

\begin{tabular}{lccc}
\hline & $\begin{array}{c}\text { Group A } \\
\mathrm{n}(\%)\end{array}$ & $\begin{array}{c}\text { Group B } \\
\mathrm{n}(\%)\end{array}$ & $\begin{array}{c}\text { P } \\
\text { value }\end{array}$ \\
\hline $\begin{array}{l}\text { Tumor grade } \\
\text { Grade I }\end{array}$ & $23(76.7)$ & $25(83.3)$ & $0.519^{\text {ns }}$ \\
Grade II & $7(23.3)$ & $5(16.7)$ & \\
Tumor stage & & & \\
Ta & $25(83.3)$ & $26(86.7)$ & $0.718^{\text {ns }}$ \\
T1 & $5(16.7)$ & $4(13.3)$ & \\
\hline
\end{tabular}

Tumor grade I was found $23(76.7 \%)$ in group A and $25(83.3 \%)$ in group B. The difference was not statistically significant $(\mathrm{p}>0.05)$. Tumor status Ta of superficial bladder was found $25(83.3 \%)$ in group A and $26(86.7 \%)$ group B. Tumor status T1 of superficial bladder was found 5 (16.7\%) in group A and 4 (13.3\%) group $B$. The difference was not statistically significant $(p>0.05)$.

\begin{tabular}{|c|c|c|c|}
\hline No. of recurrence & $\begin{array}{c}\text { Group A } \\
\mathrm{n}(\%)\end{array}$ & $\begin{array}{c}\text { Group B } \\
n(\%)\end{array}$ & $\begin{array}{c}\mathrm{p} \\
\text { value }\end{array}$ \\
\hline $3^{\text {rd }}$ month & $0(0.0)$ & $0(0.0)$ & $\overline{1.000}$ \\
\hline $6^{\text {th }}$ month & $5(16.7)$ & 4 (13.3) & $0.718^{\text {ns }}$ \\
\hline $9^{\text {th }}$ month & $0(0.0)$ & $0(0.0)$ & 1.000 \\
\hline $12^{\text {th }}$ month & $6(16.7)$ & $5(13.3)$ & $0.740^{\text {ns }}$ \\
\hline
\end{tabular}

The study showed no recurrence in follow up cystoscopy at $3^{\text {rd }}$ month in both groups. Five (16.7\%) patients were found recurred in group A and 4 (13.3\%) in group $B$ at $6^{\text {th }}$ month follow up. The difference was not statistically significant $(\mathrm{p}>0.05)$. At $12^{\text {th }}$ month, six $(20.0 \%)$ patients was found recurred in group $\mathrm{A}$ and $5(16.7 \%)$ in group B. The difference was not statistically significant $(\mathrm{p}>0.05)$.

Table V : Distribution of side effect in respondents after intervention with intravesical chemotherapy

\begin{tabular}{lccc}
\hline Side effect & $\begin{array}{c}\text { Group A } \\
\mathrm{n}(\%)\end{array}$ & $\begin{array}{c}\text { Group B } \\
\mathrm{n}(\%)\end{array}$ & $\begin{array}{c}\text { P } \\
\text { value }\end{array}$ \\
\hline Yes & $0(0.0)$ & $2(6.7)$ & $0.150^{\text {ns }}$ \\
No & $30(100.0)$ & $28(93.3)$ & \\
\hline
\end{tabular}


Side effect was found in $2(6.7 \%)$ patients in group B and not found in group A. Side effect was not statistically significant $(p>0.05)$ between two groups.

\section{Discussion:}

Bladder cancer is a disease of older individuals with greater than $90 \%$ of diagnosis in patients more than 55 years of age; although uncommon, bladder cancer can occur in young adults and even in children. In this study the mean age of diagnosis was $61.8 \pm 13.7$ years in Group A (MMC immediate single dose group) and was $62.7 \pm 13.6$ years in Group B (MMC multi-dose group). This difference of age among groups was insignificant statistically. The treatment protocol was the same in all age group because the disease progression is not influenced by age and sex (Smith et al. 2016). ${ }^{14}$

Sex incidence has been reported 4:1 in between male and female. ${ }^{9}$ In this study the ratio between male and female in group A was 3:1 and in group B 5.4:1. The difference of male female ratio in between the groups was not statistically significant.

In the present study mean number of tumor in Group A was $1.8 \pm 0.8$ and in Group B was 1.9 \pm 0.7 , mean size of the tumor in Group A was $2.13 \pm 0.78 \mathrm{~cm}$. and in Group B was $2.05 \pm 0.84 \mathrm{~cm}$.

The distribution of grade of tumor was in Group A, 23 patients $(76.7 \%)$ were grade I and 7 patients $(23.3 \%)$ were grade II, in Group B, 25 patients $(83.3 \%)$ were grade I and 5 patients (16.7\%) were grade II.

Stage of the tumor was in Group A, 25 patients $(83.3 \%)$ were $\mathrm{Ta}, 5$ patients $(16.7 \%)$ were $\mathrm{T} 1$, in Group B, 26 patients $(86.7 \%)$ were $\mathrm{Ta}$ and 4 patients $(13.3 \%)$ were T1.

Solitary recurrences were seen at $6^{\text {th }}$ month of followup. The number of recurrences was 5 in Group $A$ and was 4 in Group B. The difference of recurrences between two groups is not significant. Overall tumor free rate was 83.3\% in Group A and 86.7\% in Group B. The result of study is similar to other studies. ${ }^{15-18}$

In the $12^{\text {th }}$ month of follow-up, it was seen that 6 cases in Group A and 5 cases in Group B were recurred, with recurrence free rate of $80.0 \%$ and $83.3 \%$ respectively. The result of the present study was similar with the study of Ali-el-Dein et al. ${ }^{15}$, Bouffioux et al. ${ }^{16}$ Liu et al. ${ }^{17}$ Tolley et al .[18] and Solsona. ${ }^{19}$

The side effect of intravesical Mitomycin C was absent in Group A. But only two patients (6.7\%) complained mild dysuria in Group B. The side effect of Mitomycin $\mathrm{C}$ following prolonged treatment was reported $2 \%$ to $24 \%{ }^{10}$ compatible with present study.

\section{Conclusion}

This study concluded that the results of post TURBT immediate single dose and delayed multi-dose regimen of Mitomycin $C$ therapy in the management of superficial transitional cell carcinoma of the urinary bladder is almost same.

\section{References}

1. Konety BR. and Carroll PR. 2013. Urothelial carcinoma. Cancers of the bladder, Ureter, and Renal pelvis', in JW McAninch, TF Lue, (eds), Smith \& Tanagho's General Urology, $18^{\text {th }}$ edn, McGraw-Hill, USA, 2013; 310-329.

2. Kirkali Z, Chan T, Manoharan M, Algaba F, Busch C, Cheng L, et al. Bladder cancer: epidemiology, staging and grading, and diagnosis. Urology. 2005 Dec 1;66(6):4-34.

3. Parkin DM, Whelan SL, Ferlay J, Teppo L, Thomas DB. Cancer incidence in five continents Vol. VIII. IARC scientific publications. 2002;155.

4. Jemal A, Bray F, Center MM, Ferlay J, Ward E, Forman D. Global cancer statistics. CA: a cancer journal for clinicians. 2011 Mar 1;61(2):69-90.

5. Babjuk MA, Böhle M, Burger E, Compérat E, Kaasinen J, Palou M, et al. 2015, 'Guidelines on Non-muscle-invasive Bladder Cancer (Ta, T1 and CIS)', European Association Of Urology. Available from: http://www.uroweb.org/professional resources/guidelines/online. [20 November 2016].

6. Aldousari S, Kassouf W. Update on the management of non-muscle invasive bladder cancer. Canadian Urological Association Journal. 2010 Feb;4(1):56-60.

7. Kassouf W, Kamat AM, Zlotta A, Bochner BH, Moore R, So A, et al. Canadian guidelines for treatment of non-muscle invasive bladder cancer: a focus on intravesical therapy. Canadian Urological Association Journal. 2010 Jun;4(3):168173.

8. Sylvester RJ, Brausi MA, Hoeltl W, Powell PH, Whelan P, Gorlia T, et al. Long-term efficacy results of EORTC GU Group study 30911 comparing epirubicin, bacillus Calmette-Guerin (BCG), and BCG plus isoniazid in patients with 
intermediate and high risk stage TaT1 papillary carcinoma of the bladder. European Urology Supplements. 2008 Mar 1;7(3):298-304.

9. Bladder Cancer Clinical Guideline Update Panel, 2007. Guidelines for the management of nonmuscle invasive bladder cancer (stages Ta, T1, and Tis): 2007 update. American Urological Association. Available from: http:// www.auanet.orq/content/quidelines andqualitycare/ clinicalquidelines.cf $m$ ? $\mathrm{Sub}=\mathrm{bc}$. [20 November 2016].

10. Hall MC, Chang SS, Dalbagni G, Pruthi RS, Seigne JD, Skinner EC, et al. Guideline for the management of nonmuscle invasive bladder cancer (stages Ta, T1, and Tis): 2007 update. The Journal of urology. 2007 Dec 1;178(6):2314-30.

11. Shariat SF, Chade DC, Karakiewicz PI. Update on intravesical agents for non-muscle-invasive bladder cancer. Immunotherapy 2010; 2: 381-92.

12. Monzon AJ, Gomez JMF, Bramada SE. and Mugica MA, Therapeutic effect of immediate postoperative Mitomycin C in patients with lowrisk Non-Muscle-Invasive Bladder tumors. Actas Urol Esp. 2008; 32(8): 811-820.

13. Ather, M.H., Aziz, S. and Sulaiman, M.N., 2007. Single instillation of mitomycin $C$ reduces 1 st year recurrence following transurethral resection of non-muscle invasive bladder cancer. Journal of Ayub Medical College, 19(4), pp. 18-20.

14. Smith AK, Matin MSF. and Jarrett TW. Urothelial tumors of the upper urinary tract and Ureter. in LR Kavoussi, AC Novick, AW Partin, CA Peters, AJ Wein, (eds), Campbell-Walsh Urology, 11th edn, Elsevier Saunders, Philadelphia 2016; 1365-1402.
15. Ali el Dein, B., Nabeeh, A., el Baz, M., Shamaa, S. and Ashamallah, A., 1997. Single dose versus multiple instillations of epirubicin as prophylaxis for recurrence after transurethral resection of $\mathrm{pTa}$ and pT1 transitional cell bladder tumours: a prospective, randomized controlled study. BJU International, 79(5), pp.731-735.

16. Kurth K, Bono A, Oosterlinck W, Boeken Kruger C, De Pauw M, Sylvester R. Intravesical adjuvant chemotherapy for superficial transitional cell bladder carcinoma: results of 2 EORTC randomized trials with mitomycin $C$ and doxorubicin comparing early versus delayed instillations and short term versus long term treatment. J Urol. 1995;153:934-41.

17. Liu B, Wang Z, Chen B, Yu J, Zhang P, Ding Q, Zhang Y. Randomized study of single instillation of epirubicin for superficial bladder carcinoma: long-term clinical outcomes. Cancer investigation. 2006 Jan 1;24(2):160-3.

18. Tolley DA, Hargreave TB, Smith PH, Williams JL, Grigor KM, Parmar MK, et al. Effect of intravesical mitomycin C on recurrence of newly diagnosed superficial bladder cancer: interim report from the Medical Research Council Subgroup on Superficial Bladder Cancer (Urological Cancer Working Party). British medical journal (Clinical research ed.). 1988 Jun 25;296(6639):1759-1761.

19. Solsona E, Iborra I, Ricos JV, Monros JL, Casanova J, Dumont R. Effectiveness of a single immediate mitomycin $\mathrm{C}$ instillation in patients with low risk superficial bladder cancer: short and long-term followup. The Journal of urology. 1999 Apr 1;161(4):1120-3. 